\title{
A SYNTHETIC METHOD FOR EXAMINATION OF POTENTIAL RELIABILITY AND SAFETY LEVEL DEMONSTRATED BY TECHNICAL FACILITIES DURING THEIR LIFETIME
}

\section{SYNTETYCZNA METODA BADANIA POTENCJAŁU NIEZAWODNOŚCI I BEZPIECZEŃSTWA OBIEKTU TECHNICZNEGO W PROCESIE EKSPLOATACJI}

\author{
Paweł Lindstedt ${ }^{1}$, Rafał Grądzki ${ }^{2}$ \\ ${ }^{1}$ Air Force Institute of Technology, \\ Ksiecia Boleslawa 6 Street, 01-494 Warsaw, POLAND, \\ e-mail: sekretariat.naukowy@itwl.pl \\ ${ }^{2}$ Bialystok Technical University, Department of Mechanical Engineering, \\ Wiejska 45C Street, 15-351 Bialystok, POLAND, \\ e-mail: rgradzki84@gmail.com
}

\begin{abstract}
The paper presents fundamentals for an innovative method that takes advantage of diagnostic information defined with participation of an expert. (presented as a score of points). Defined number of points is assigned to each signal change, depending on the signal value and the moment when the change occurs, whilst the number of points is preliminary defined by an expert. The proposed innovative method consists in the use of signals represented by the scores to determine combined status equations [3,5] for parameters of the adjustment control state and technical state (equations 3 and 4) and then parameters of reliability and safety (equations 5 and 6). Such an approach enables continuous monitoring of the reliability and safety states of facilities during their lifetime. The presented approach may prove to be extremely useful as it unambiguously presents wear and tear of the facilities and enables to predict when the facilities should be repaired (overhauled).
\end{abstract}

Key words: diagnostic, safety, reliability

Streszczenie: W artykule przedstawiono założenie nowatorskiego sposobu wykorzystywania informacji diagnostycznej określonej z udziałem eksperta przedstawionej w postaci liczby punktów. Każdej zmianie sygnału (w zależności od jej wielkości i chwili pojawienia) przypisana jest odpowiednia ustalona przez ekspertów ocena postaci liczby punktów. Zaproponowana nowa metoda polega na wykorzystaniu sygnałów w postaci punktowej do wyznaczenia ze sprzeżonych równań stanu $[3,5]$ parametrów stanu regulacji i stanu technicznego (równania 3,4) a następnie stanu niezawodności i bezpieczeństwa obiektu (równania 5,6). Pozwoli to na ciagła kontrolę stanu niezawodności i bezpieczeństwa obiektu w czasie eksploatacji. Opisany sposób może okazać się bardzo przydatny, ponieważ jednoznacznie przedstawia zużywanie się obiektu i pozwala przewidzieć kiedy obiekt powinien być naprawiany (remontowany).

Słowa kluczowe: diagnostyka, bezpieczeństwo, niezawodność 


\section{Introduction}

Optimal operation and maintenance of technical equipment require permanent or periodical identification of its parameters that represent the status of its adjustment control, diagnostics and reliability $[1,6]$.

Adjustment control consists in continuous monitoring of relations between automation signals where they serve as a basis to assess operation quality (functional performance) of technical facilities. It is the adjustment control accuracy that guarantees correct operation of the facilities, its uniform and gradual wear and tear and dependable execution of all its functionalities [1, $5]$.

Diagnostics investigates relationships between alterations of technical (physical) state demonstrated by the equipment and measurable changes in mutual interaction between the equipment and its environment. Diagnostic examination of the equipment is carried out by means of indirect methods without dismantling of the hardware.

The information acquired about changes in technical state of facilities makes it possible to implement optimum operation strategy, adequate to the technical state of the equipment with due consideration to high safety and reliability standards $[5,6,7]$.

Reliability is a feature of facilities that is defined as a probability of faultfree operation, i.e. execution of all the required functions and activities over a specific period of time. The theory of reliability is aimed at computation of estimators for reliability indices on the basis of faults that could have arisen during a specific operation period of the equipment set and then calculation of reliability characteristics $[1,7,8]$.

All the facilities should be perfectly adjusted, "sound and healthy" in terms of their technical state and available for operation at any moment of time. Current computation of characteristics that reflect operation status, technical and reliability condition of the equipment is therefore the basic task that is to be performed by operators and maintenance staff. To do so one has to acquire performance, qualitative and quantitative information about adjustment control, diagnostics and reliability in relation to both the facilities and their environment.

Having in mind that only incomplete and inaccurate information is usually available, both in relation to the facilities and to their environment, the information can be supplemented by appropriate and relevant expert knowledge $[2,10,11]$. 


\section{Cybernetic system for operation of equipment}

Operation and maintenance of technical equipment are issues of crucial importance for systems dedicated for their utilization (Fig. 1). All systems designed for utilization of technical facilities deliver the required useful working capabilities provided that they are properly supplied with materials and energy. However, in parallel to their beneficial role, the facilities are subject to continuous deterioration of their parameters. The facilities malfunction, undergo wear and tear processes and become more and more defective. Technical and maintenance staff attempts to impede these detrimental processes by means of appropriate adjustment control, diagnostics and investigation of the facilities' dependability. Knowledge that is necessary for optimum adjustment control of the equipment as well as information about its technical state present the prerequisites that, having been entered into the equipment operation system, contribute to enormous increase in the system orderliness (growth of redundancy), which results in the increase of the system efficiency (the entered information is transformed into savings of materials and power consumption) $[1,6]$.

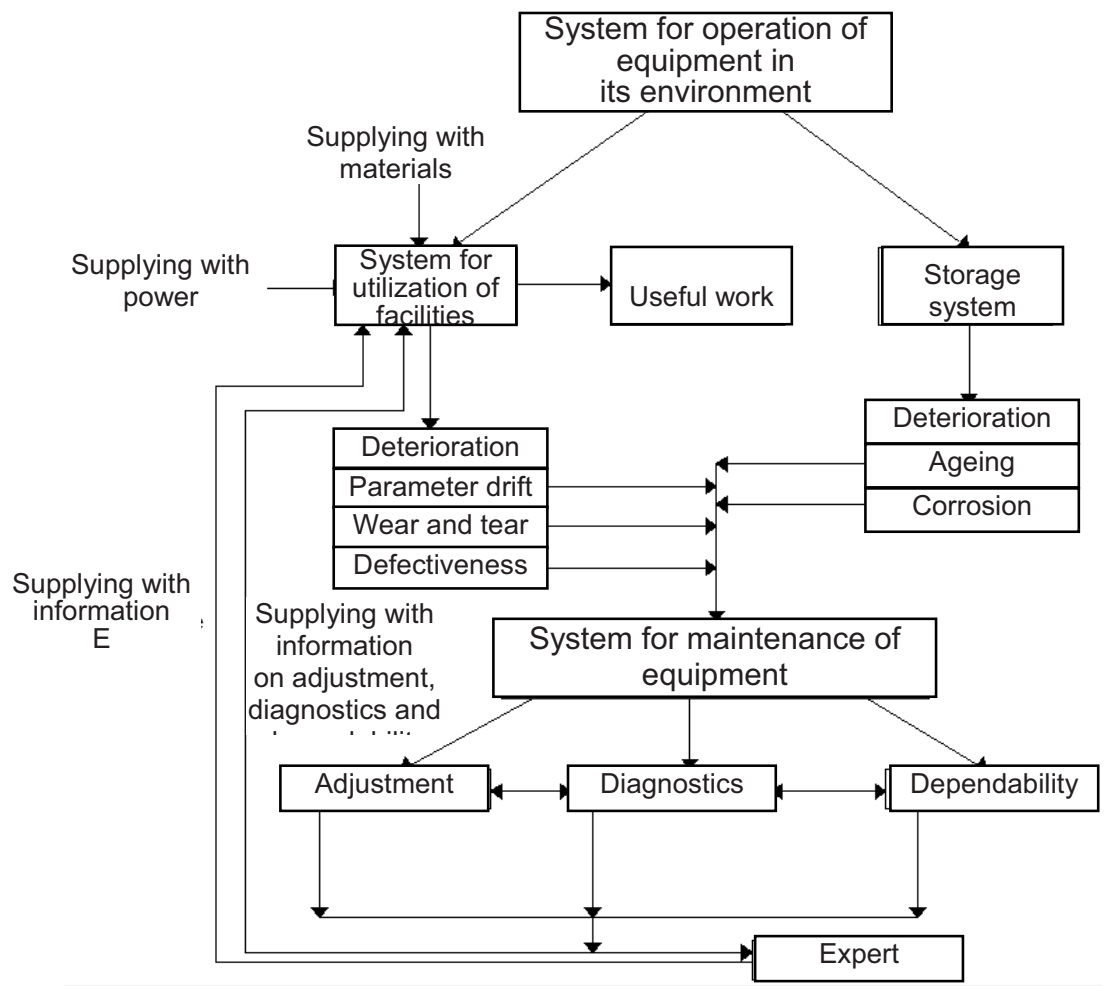

Fig.1. One-wire diagram of a cybernetic system for operation and maintenance of equipment 
It must be noticed that a system for operation of equipment, beside deterministic information (adjustment control and diagnostics) as well as probabilistic one (dependability) can be supplied with heuristic knowledge provided by experts.

\section{Structure and operation of equipment in their environment}

Structural view of a typical Diesel engine is presented in Fig. 2.

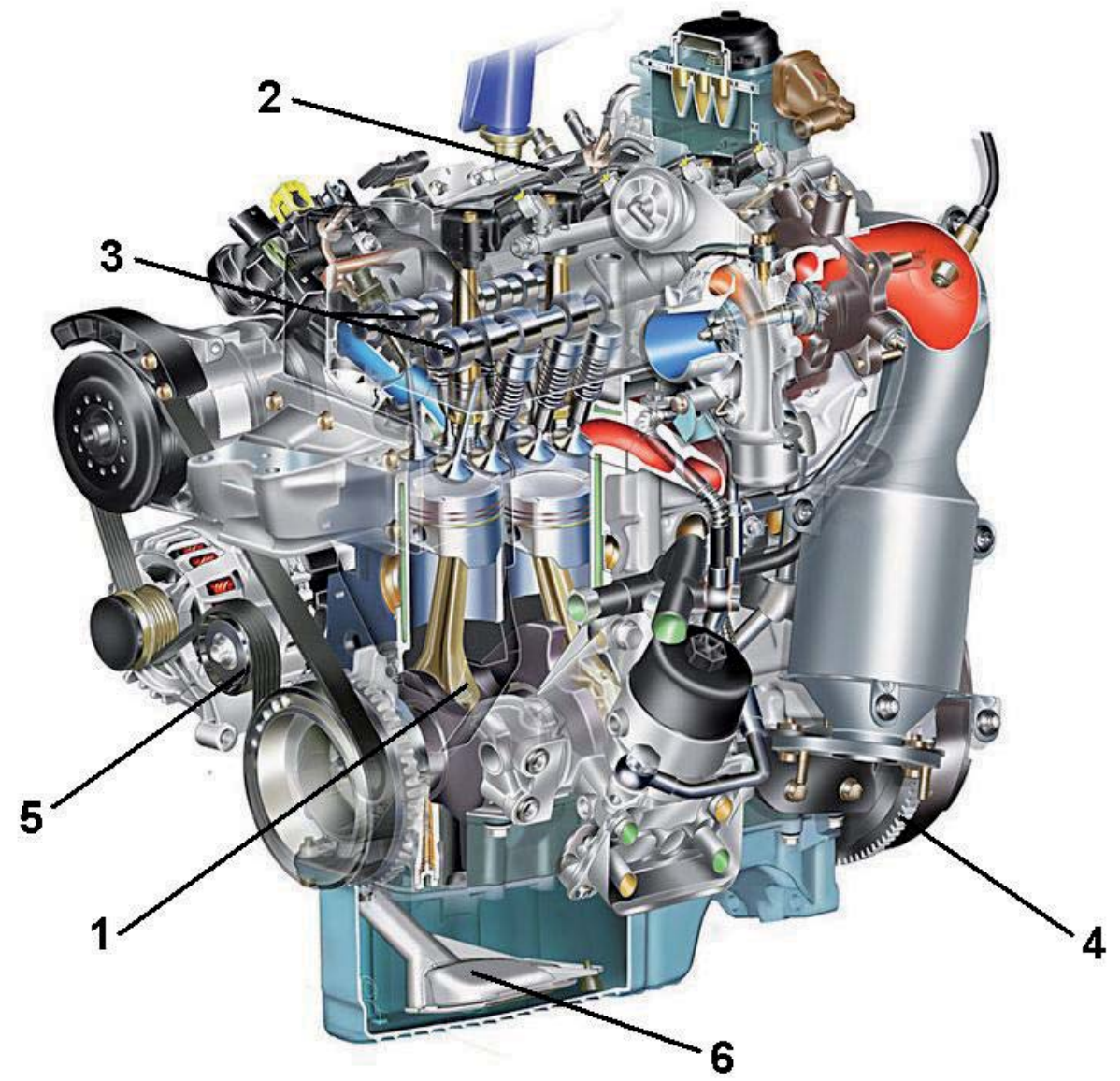

Fig. 2. Structural view of a Diesel engine

1- crankshaft and piston system, 2- supply system, 3- timing gear system, 4- starting system, 5- cooling system, 6- lubrication system.

A Diesel engine (Fig. 2) incorporates components that contribute to performing the desired functionalities. The main component of the engine is its cylinder block that incorporates cylinders with pistons where chemical energy is converted into mechanical power. Moreover, the engine 
encompasses various systems that are necessary for its sound operation and responsible for specifically defined tasks.

The following subsystems are distinguished:

- the crankshaft and piston system that changes reciprocating movements of the piston into rotations of the crankshaft;

- the timing system that controls the process of supplying fresh air and fuel mixture or air alone to cylinders as well as expelling exhaust gases from cylinders;

- the supply system that supplies air and fuel mixture or air and fuel separately to cylinders

- lubrication system that delivers oil between mating parts of the engine in order to reduce resistance and friction;

- cooling system with the task to maintain the optimum temperature of the engine to enable the most efficient operation of the engine;

- starting system dedicated to the engine kick-off, usually it is an electric starter.

Operation principle of a Diesel engine is presented in Fig. 3.

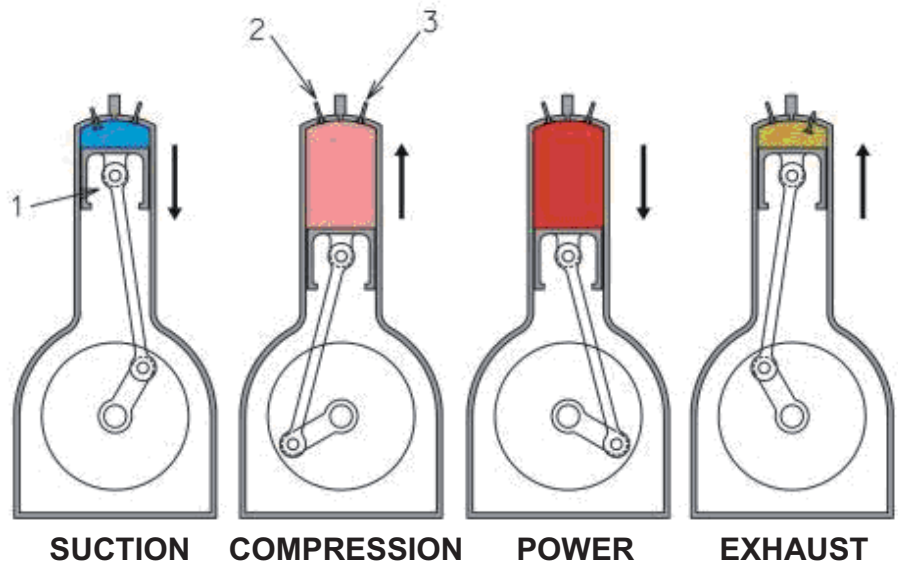

Fig. 3. Operation cycle of a Diesel engine Operation of the engine can be split into four phases:

\section{Suction stroke (1)}

The piston moves down from its topmost position to the lower dead point with simultaneous formation of negative pressure inside the cylinder. During the movement the suction valve opens, which allows to intake fuel and air mixture from the carburettor (or an injection system and air channels) via an intake passage located behind the suction valve that closes the passage. The mixture is supplied to the inner space of the cylinder, 
between the piston and the cylinder head. When the piston moves beyond the lower dead point the suction valve closes.

\section{Compression stroke (2)}

The piston moves up towards the cylinder top with simultaneous compression of the air and fuel mixture. Both valves, i.e. the suction valve and the exhaust valve, remain closed. Compression is carried out under significant pressure, usually as much as down to ca. one tenth of the initial volume of the mixture. But before the minimum volume is achieved (1-2 $\mathrm{mm}$ or ca. $5^{\circ}$ of the crankshaft rotation before the topmost position), the ignition occurs. The purpose of the ignition is to combust the entire volume of the mixture at the moment when the piston passes by the topmost position and can be bumped back by expansion of exhaust gases, which initiates the power stroke of the cylinder.

\section{Power (working) stroke (3)}

In case of Diesel engines as well as those with electronically controlled direct injection of fuel, the fuel injection and self-ignition occur right before the moment when the piston reaches the topmost position. The exhaust valve and the suction valve are both closed. The piston is pushed back with great force as pressure of nearly 100 bars is produced inside the combustion chamber, which may be equivalent to the pressure force of 5 tons on the piston. Such force must be transmitted from the piston top plate to the crankshaft via the connecting rod. This compels the movement of the piston into the lower dead point. The power from the one stroke must be sufficient for the engine to perform the other three idle strokes. It is why internal combustion engines usually have more than one cylinder to assure uniform operation.

\section{Exhaust stroke (4)}

Even before the piston reaches the lower dead point, the exhaust valve opens and exhaust gases, still compressed to the defined pressure, can leave the cylinder via the exhaust system. The piston moves up until its topmost position while the exhaust valve still remains open. Thus the remaining exhaust gases are pushed out of the cylinder and a so called 'swing' is performed, i.e. the exhaust valve closes, the suction valve opens and the entire cycle starts over.

Such engines operate under heavy duty conditions, in a fast-changing environment that directly affects their state of adjustment control, technical state and dependability. Formal description of the environment is really troublesome as it must take account of a variety of information associated with a number of issues, e.g. the condition of the engine suspension in the 
vehicle, the driver's qualifications as well as the route description and the road pavement condition. Therefore the conclusion can be drawn that the description of the environment must incorporate both deterministic and probabilistic models along with heuristic ones that are based on expertise knowledge [2, 4].

\section{Standard and special examination of technical facilities during their lifetime}

Measurement of smoke content in exhaust gases is one of typical examinations within comprehensive diagnostic of engines. The smoke content results from the presence of solid particles (e.g. soot) and other components $\left(\mathrm{CO}_{2}, \mathrm{CO}, \mathrm{HC}, \mathrm{NO}_{\mathrm{x}}\right)$. Examination of smoke content in exhaust gases also enables early detection of motor defects. Increased emission of only partly combusted or even non-combusted fuel indicates problems with combustion that may arise as a result of incorrect preparation of air-fuel mixture as a result of defective or worn atomizing nozzles, incorrect settings for initial moment of compression or excessive consumption of lubricating oil. Irregularities in combustion may lead to increased smoke content in exhaust gases regardless of the engine states. Such irregularities are detectable due to a specific colour of exhaust gases. Recognition of the smoke colour helps to determine whether the increased level of smoke is caused by the presence of soot particles, engine oil, fuel or water.

Another signal that can be used during the engine lifetime is noise, which is a very specific sound produced by individual vehicle parts in movement. The predominant factor in the overall noise produced by Diesel motors (with sufficiently remote exhaust system) is the noise of mechanical origin. Aerodynamic components of the noise, originating from the combustion process as well as the suction and exhaust systems, are usually dominated by interferences produced by bumps of pistons against cylinder walls, vibration of the engine body and operation of the timing and injection systems. Therefore, the deployment of microphones at various locations in the engine is of crucial importance. Noise measurements are carried out by a sound level meter with classes 0 or 1 on the correction curve $\mathrm{A}$ and for time constant of the meter F.

Fuel consumption is yet another factor that provides information on technical soundness of a vehicle engine. Measurements of fuel consumption are performed on a test bench (i. e. a chassis dynamometer) during simulated city and highway driving with predefined mileage, scheduled speed and acceleration values that correspond to actual conditions of the vehicle operation. Fuel consumption is not calculated by the weight 
measurements but from the thermal balance expressed by amount of carbon dioxide $\mathrm{CO}_{2}$ and converted to the factor $\left[\mathrm{dm}^{3}\right.$ per $100 \mathrm{~km}$ ].

Public domain data also provide information on road pavements: whether it is asphalt, sand, gravel or macadam surface and whether the road is flat or any of the uphill or downhill directions predominate. Other parameters that are used for simulation include air resistance that must be overcome by the bus, number of passengers in the bus and the distance between stops.

Expert knowledge acquired e.g. from drivers is a specific form of information. Drivers may spot various irregularities of the engine operation (knocks, delays, motor kills at idle rpm, etc.). Additional information can be obtained from the drivers who watch how the driven road looks like: whether it has been reconstructed or has numerous holes or ruts, the amount of traffic at various times of the day as well as the number of bus passengers that are carried over specific distance segments.

Psychological and physical state of a driver along with his competence level, driving style, job seniority, etc. must also be taken into account.

All the above information, arranged in an appropriate and coherent manner, provide all the information about the effect of the ambient conditions on the examined vehicle and therefore on its engine.

The tests were carried out with the use of two buses MAN NG272. The engines were examined with a smoke content meter AT600L. Measurements were carried out at the engine temperature of $80^{\circ} \mathrm{C}$. The first measurement took place during the so called 'blow through' whilst the second value was the average of all the readouts obtained at various working rpm of the bus engine. The maximum value that is allowed for those bus types is $2,51[1 / \mathrm{m}]$. The subsequent test consisted in the calculation of the average fuel consumption, which was always performed at the end of every month. The last check related to the technical facility included noise measurements with the use of the AS-200 instrument dedicated for metering sound level produced by automotive vehicles. The measurements included the peak value as well as the average value for three readouts. The maximum allowed level for the noise is $98 \mathrm{~dB}$. All the facility-related values were recorded as cartesian pairs $\mathrm{X} / \mathrm{Y}$ where $\mathrm{X}$ stands for the measured value and $\mathrm{Y}$ is the bus mileage.

To assess the ambient conditions it was necessary to investigate the route the bus usually drives. The route was then defined with the route number (four routes). Each examined route was structured into segments: 1 - route with numerous downhill drives with sound asphalt pavement; 2 - flat route with sound asphalt pavement; 3 - route with numerous uphill drives with sound asphalt pavement; 4 - route with numerous downhill drives with poor asphalt pavement; 5 - flat route with poor asphalt pavement; 6 - route with 
numerous uphill drives with poor asphalt pavement. The subsequent operation consisted in calculating the percentage ratio for each segment, i.e. how much of the entire route it presents with subsequent calculation of a common value that represented the road condition over the entire distance. The calculations also concerned job seniority of drivers, their personal experience and driving skills. All the acquired data were then summarized in Table 1 and Table 2.

Table 1. Results of diagnostic examinations for the engine MAN NG272 with its number 874 over the year 2009

\begin{tabular}{|c|c|c|c|c|c|c|c|c|c|c|c|c|}
\hline $\begin{array}{c}\text { Time } \\
\text { Signals }\end{array}$ & I & II & III & IV & V & VI & VII & VIII & IX & X & XI & XII \\
\hline $\mathrm{D}_{1}$ & 39.28 & 44.29 & 44.78 & 42.24 & & & & & & & & \\
\hline $\mathrm{D}_{2}$ & 43.32 & 46.54 & 45.47 & 42.24 & & & & & & & & \\
\hline $\mathrm{D}_{3}$ & & & 1.07 & & & & & & & & & \\
\hline $\mathrm{D}_{4}$ & & & 0.06 & & & & & & & & & \\
\hline $\mathrm{D}_{5}$ & & 94 & & & & & & & & & & \\
\hline $\mathrm{D}_{6}$ & & 91 & & & & & & & & & & \\
\hline $\mathrm{D}_{7}$ & 3 & 1 & 2 & 2 & & & & & & & & \\
\hline $\mathrm{D}_{8}$ & 1009210 & 1012810 & 10165381018880 & & & & & & & & \\
\hline
\end{tabular}

$\mathrm{D}_{1}$ - average fuel consumption w/o heating of the bus $[1 / 100 \mathrm{~km}]$

$\mathrm{D}_{2}$ - average fuel consumption with heating of the bus $[1 / 100 \mathrm{~km}]$

$\mathrm{D}_{3}$ - smoke content during 'blowing through' of the engine $[1 / \mathrm{m}]$

$\mathrm{D}_{4}$ - smoke content during engine operation $[1 / \mathrm{m}]$

$\mathrm{D}_{5}$ - peak value for the noise level [dB]

$\mathrm{D}_{6}$ - average value for the noise level [dB]

$\mathrm{D}_{7}$ - information from drivers: knocks, engine self-kills, etc.,

$\mathrm{D}_{8}$ - bus mileage $[\mathrm{km}]$

Table 2. Examination results for ambient conditions of the engine MAN

NG272 with the number 874 over the year 2009.

\begin{tabular}{|c|c|c|c|c|c|c|c|c|c|c|c|c|}
\hline SignaI & I & II & III & IV & V & VI & VII & VIII & IX & X & XI & XII \\
\hline $\mathrm{U}_{\mathrm{K} 1}$ & 31 & 31 & 31 & 31 & 31 & & & & & & & \\
\hline $\mathrm{U}_{\mathrm{K} 2}$ & 180 & 168 & 176 & 180 & 180 & & & & & & & \\
\hline $\mathrm{U}_{\mathrm{K} 3}$ & & & & & & & & & & & & \\
\hline $\mathrm{U}_{\mathrm{D} 1}$ & 3 & 5 & 3 & 17 & 24 & & & & & & & \\
\hline $\mathrm{U}_{\mathrm{D} 2}$ & 14.8 & 8.8 & 14.8 & 11.6 & 12.4 & & & & & & & \\
\hline $\mathrm{U}_{\mathrm{D} 3}$ & & & & & & & & & & & & \\
\hline $\mathrm{U}_{\mathrm{D} 4}$ & 6 & 3 & 1 & & 1 & & & & & & & \\
\hline
\end{tabular}

$\mathrm{U}_{\mathrm{K} 1}$ - personal experience of a driver [years]

$\mathrm{U}_{\mathrm{K} 2}$ - number of work hours per each month [h]

$\mathrm{U}_{\mathrm{K} 3}$ - driving skills

$\mathrm{U}_{\mathrm{D} 1}$ - route number 
$\mathrm{U}_{\mathrm{D} 2}-$ route distance $[\mathrm{km}]$

$\mathrm{U}_{\mathrm{D} 3}$ - route type

$\mathrm{U}_{\mathrm{D} 4}-$ other factors - wind, glace, etc.,

Signals $\mathrm{D}_{1}, \mathrm{D}_{2}, \mathrm{D}_{3}, \mathrm{D}_{4}, \mathrm{D}_{5}, \mathrm{D}_{6}$ as well as $\mathrm{U}_{\mathrm{K} 1}, \mathrm{U}_{\mathrm{K} 2}, \mathrm{U}_{\mathrm{K} 3}, \mathrm{U}_{\mathrm{K} 4}, \mathrm{U}_{\mathrm{D} 1}, \mathrm{U}_{\mathrm{D} 2}, \mathrm{U}_{\mathrm{D} 3}$, $\mathrm{U}_{\mathrm{D} 4}$ are of different physical nature so they must be brought to a common form $\mathrm{D}_{1 \mathrm{P}}, \mathrm{D}_{2 \mathrm{P}}, \mathrm{D}_{3 \mathrm{P}}, \mathrm{D}_{4 \mathrm{P}}, \mathrm{D}_{6 \mathrm{P}}$ and $\mathrm{U}_{\mathrm{K} 1 \mathrm{P}}, \mathrm{U}_{\mathrm{K} 2 \mathrm{P}}, \mathrm{U}_{\mathrm{K} 3 \mathrm{P}}, \mathrm{U}_{\mathrm{K} 4 \mathrm{P}}, \mathrm{U}_{\mathrm{D} 1 \mathrm{P}}, \mathrm{U}_{\mathrm{D} 2 \mathrm{P}}, \mathrm{U}_{\mathrm{D} 3 \mathrm{P}}$, $\mathrm{U}_{\mathrm{D} 4 \mathrm{P}}$. On the basis of the expertise knowledge all the signals can be represented as 'scored points' (figures) $[2,5,10]$. It enables to determine resulting (comprehensive) diagnostic and environment-related signals:

$$
\begin{aligned}
& D_{K}=\sqrt{D_{1 P}+D_{2 P}+D_{3 P}+D_{4 P}+D_{5 P}+D_{6 P}} \\
& U=\sqrt{U_{K 1 P}+U_{K 2 P}+U_{K 3 P}+U_{K 4 P}+U_{D 1 P}+U_{D 2 P}+U_{D 2 P}+U_{D 4 P}}
\end{aligned}
$$

After such preparation of the acquired information, the status equation can be applied to analysis of the operation condition of the facilities.

\section{Control and technical potential of facilities}

Each driver operates the bus controls and then interacts with its environment (acceleration, deceleration, turning left and right). This interaction is efficient when technical condition of the bus is sound. Due to its everyday operation, each bus is subject to the process of natural deterioration of parameters (noise, smoke, fuel consumption). Intensity of deterioration depends on the changing environment where the bus travels. These facts can be expressed by a system of combined equations $[3,5,9]$ :

$$
\begin{aligned}
& \frac{d U}{d t}=a_{R} U+b_{R} D_{k} \\
& \frac{d D_{k}}{d t}=a_{T} D_{k}+b_{T} U
\end{aligned}
$$

where: $U$ - variable of the operation status (signal of operation), $D_{k}-$ signal for technical soundness of the bus (ambient environment), $a_{R}$-parameter of control status, $b_{R}-$ parameter that represents interrelationship between technical soundness and adjustment control state, $a_{T}$ - parameter of the bus technical soundness, $b_{T}$ - parameter that represents the influence of the control status onto technical soundness of the bus.

The $a_{R}$ parameter represents the state of the mutual interrelations between the engine and the ambient environment. It chiefly depends on driver's behaviour and on the effect of the technical facility condition onto driver's activities.

The $a_{T}$ parameters stand for technical soundness of the bus (technical state) and depend on diagnostic signals and signals that results from driver's operations and ambient environment signals. 
When parameters of the control status $a_{R}$ and technical status $a_{T}$ are known along with their dynamic properties, subsequent parameters associated with the engine reliability and safety can be determined. Thus, safety potential $a_{b}$ as well as reliability potential $a_{N}$ can be calculated in the following way: $[3,5,8]$ :

$$
\begin{aligned}
& \frac{d a_{R}}{d t}=a_{b} a_{R}+b_{b} a_{T} \\
& \frac{d a_{T}}{d t}=a_{N} a_{T}+b_{N} a_{R}
\end{aligned}
$$

where: $a_{b}$ - safety potential of the bus engine, $b_{b}$ - parameter that stands for impact intensity of technical status onto safety potential of the engine, $a_{N}$ reliability potential of the engine, $b_{N}$ - parameter that stands for impact intensity of operation status onto safety potential of the engine.

The foregoing equations $(5,6)$ can serve as a basis for multiparametric assessment of the equipment status (control, diagnostics, safety and reliability). That status can be defined in quantitative manner by four parameters: $a_{R}, a_{T}, a_{b}, a_{N}$ as well as four other parameters: $b_{R}, b_{T}, b_{b}$, $b_{N}$ that define how far the ambient environment affects the equipment status.

\section{Conclusions}

Operation of technical equipment always includes diagnostic procedures intended to determine both current and future technical state of the equipment. For complex and advanced technical facilities, several diagnostic methods are applicable, these methods base on information in various forms (signals from the facilities and from its ambient environment). These methods are subject to permanent development, in particular when full and complete information about the technical state of the facilities is not available. The paper presents fundamentals for an innovative method that takes advantage of diagnostic information (presented as a score of points). Defined number of points is assigned to each signal change, depending on the signal value and the moment when the change occurs, whilst the number of points is preliminary defined by an expert. The method that has been already in use assumes simple summation of all the scores and the sum would determine the interval of the facility state and the degree of its wear and fatigue [2,9]. The proposed innovative method consists in the use of signals represented by the scores to determine combined status equations [3, 5] for parameters of the adjustment control state and technical state (equations 3 and 4) and then parameters of reliability and safety (equations 
5 and 6). Such an approach enables continuous monitoring of the reliability and safety states of facilities during their lifetime. The presented approach may prove to be extremely useful as it unambiguously presents wear and tear of the facilities and enables to predict when the facilities should be repaired (overhauled).

\section{References}

[1] Ashby R. W.: Introduction to Cybernetics, PWN, Warszawa 1963.

[2] Bukowski L.: Prediction of Reliability and Safety for Automated Systems. Proceedings of the $21^{\text {st }}$ School of Reliability, Szczyrk, 2003.

[3] Cempel C.: Theory and Engieering Practice of Systems, Wyd. Naukowe Instytutu Technologii Eksploatacyjnej PIB, Poznań 2006.

[4] Günther H.: Diagnostics of Diesel Engines, Wyd. Komunikacji i Łaczności, Warszawa 2006.

[5] Lindstedt P.: The Method of complex worthiness assessment of an engineering object in the process of its use and service, Solid State Phenomena Vol. 144 (2009) pp 45-52.

[6] Lindstedt P.: Reliability and its relation to regulation and diagnostics in the machinery exploitation systems, Journal of KONBiN No 2/2006.

[7] Smalko Z.: Fundamentals for Technical Operation of Vehicles, Ofic. Wyd. PW, Warszawa 1998.

[8] Stoskow B. S.: Reliability of Components and Appliances of Automatic Systems, WNT, Warszawa 1973.

[9] Söderström T., Stoica P.: Identification of Systems, PWN, 1997.

[10]Szawłowski S.: Maintenance Inspection ASPA in the System of Service Operations to the Board Helicopter SH-2G, AIRDIAG Warszawa 2728.10.2005.

[11] Szczepaniak C.: Fundamentals for Modelling of the Human - VehicleEnvironment Systems, PWN, Warszawa 1999.

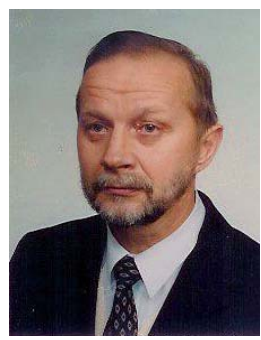

Prof. Pawel Lindstedt professor of the Air Force Institute of Technology. Research subjects: Construction and utilisation of machines, applied automatics, diagnostics and reliability of machines. His works concern diagnostics of aircraft engines, hydraulic systems, and bearing systems with functional, vibro-acoustic and wear methods.

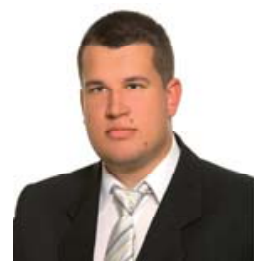

Mgr inż. Rafał Grądzki, doctoral student of the Department of Mechanical Engineering at the Białystok Technical University. Research subjects: technical diagnostics of bus engines, examination of potential reliability and safety level demonstrated by technical objects 